\title{
DESIGN OF KNOWLEDGE MANAGEMENT IMPLEMENTATION IN ISLAMIC UNIVERSITIES
}

\author{
Hakiman Hakiman $^{1 *}$, Muhammad Munadi ${ }^{2}$, Fetty Ernawati ${ }^{3}$ \\ ${ }^{1,2}$ Lecturer at Islamic Studies, Faculty of Tarbiyah, Institut Agama Islam Negeri Surakarta, Indonesia \\ ${ }^{3}$ Lecturer at Early Childhood Education Study Program, Faculty of Tarbiyah, Institut Agama Islam Negeri Surakarta, \\ Indonesia \\ "hakiman.iman@gmail.com
}

Article History: Received on $02^{\text {nd }}$ February Revised on $30^{\text {th }}$ April, Published on $20^{\text {th }}$ July 2019

\begin{abstract}
Purpose: The objective of the present study is to investigate the design of knowledge management (KM) implementation in State Islamic Universities, which possess the status of a Public Service Agency (BLU) and have implemented the remuneration system. KM is an approach to understand how knowledge is produced, stored, and distributed to improve the academic productivity.
\end{abstract}

Methodology: It is a qualitative research with a phenomenological approach, which is conducted to reveal the KM implementation by exploring the knowledge management-related activities in Islamic universities in Indonesia. Data were collected through observation, in-depth interviews, documentation and focus group discussions (FGDs). Data analysis was done through data reduction, data display, conclusions, and verification.

Main Findings: The present study indicates that KM is designed by including: First, knowledge production sourced from the outcomes of research carried out by lecturers and academic staff members with various research schemes; Second, knowledge storage is done in offline and online modes (Offline storage includes printouts, journals, and proceedings while online storage is in the form of repositories, websites, and online journals); Third, knowledge distribution is done through printouts, electronic systems, conventional lectures, and references. The KM implementation will be optimal with the support of relevant policies from the top management.

Applications: The present study provides an overview of KM design that can be used as a framework by the actors and policy makers in educational institutions.

Novelty / Originality: The novelty of the present study is on the description and the KM flow design in State Islamic Universities in Indonesia.

Keywords: Knowledge Management, Implementation, Higher Education, Islamic University, Phenomenology

\section{INTRODUCTION}

Rapid and complex challenges within the educational sphere become inevitable issues, which significantly affect the implementation of education in higher education, including the education given in Islamic universities or colleges or Pendidikan Tinggi Keagamaan Islam (PTKI). In fact, the current era is called the era of a knowledge-based society or knowledge society, as it is characterized by a high competitiveness. Such competitiveness is based on human resources and is a real challenge faced by the educational sphere, including the higher ones.

For a knowledge society, there is urgency for higher education to re-organize the institutions into an entity, which is capable of fostering creativity and intelligence, in order to keep pace with other aspects of life. The learning process at educational institutions must enable students to be creative individuals and can be attained only if such institutions enable the learning and the fostering of knowledge.

Furthermore, educational institutions should not only carry out a common response to cope with the reality. It must entail a shared commitment to perform learning-teaching activities. An organization must be able to synergize the existing knowledge and integrate it in the learning process in schools. Educational institutions serve as learning organizations. The establishment of a learning organization requires knowledge management (KM) of the entire human resources. KM is a new theme that is currently developed to improve continued teaching-learning practices in educational institutions.

Djajadiningrat (2005) argued that knowledge is continuously created by individuals in which it can be introduced and expanded through social interaction by transforming tacit knowledge into explicit knowledge. Therefore, the process of knowledge creation within an organization should be perceived as an organizational process to strengthen the knowledge created by individuals and its establishment must be a fragment of the organizational network. 
Furthermore, knowledge network must be supported by the carrying capacity of knowledge-based leadership. Burstein et al. (2003) emphasized the importance of leadership in knowledge management, which is identified as one of the most important determinants in a knowledge management program.

Sharma and Kaur (2016) claimed that KM is a vital source for the creation and transfer of knowledge, and higher education institutions potentially practice $\mathrm{KM}$ to improve operational effectiveness, competitiveness, and quality. Moreover, a higher standard, quality, and added value to services is required to ensure the fulfillment of stakeholders' assorted motives in the era of privatization of higher education. Based on this background, a study on KM in the Islamic Universities is carried out.

The implementation of KM involves the provision of facilities, including libraries, e-sources, and networks for communication and management information systems. Briefly, KM requires significant changes in the organizational culture and values, organizational structure, and reward system (Rowley, 2000).

Yusoff et al. (2012) highlighted the insignificant relationship between the implementation of KM and KM enablers. The findings indicate that there is no significant relationship between the implementation of KM and KM enablers. In addition, there is a certain enabler that causes a significant difference between KM enablers and college members, considering the variables of academic qualification, gender, and job designation.

Shafique (2015) claimed that colleges and universities have significant opportunities to apply KM practices to support every part of their mission, from education to public service, research, and development. Similarly, Yaakub et al. (2014) found that KM practices in higher education institutions were not formative and capable of standing on their own without unwavering support from the top management. There is a need to create a formative standard of KM practices in higher education institutions to enable a systematic realignment of practices in the infrastructure and strategic activities.

Based on the research objectives as explained previously, the present study is directed at revealing the design of KM implementation in Islamic universities and colleges with the status of public service agencies (BLU), including State Islamic Universities that have implemented the remuneration system.

\section{LITERATURE REVIEW}

The demand for the globalization of educational system leads to the innovation in managing higher education to support its role and function as an institution that fosters change and transformation in various fields of economics, industry, law, culture, and politics. Drucker (2011) claimed that the basic economic resources are not capital, natural resources, labor, but knowledge. Furthermore, Drucker stated that this global change leads to the phenomenon of shifting economic sources from money capital or natural resources into knowledge capital.

Mishra (2013) suggested that the internationalization of a higher education institute is where the mutual sharing of knowledge, skills and research occurs with the aim of promoting it for the benefits of national and international development. Excellent organizations do not necessarily compel the availability of tangible assets like financial, building, land, technology, market position, etc., but instead rely more on intangible knowledge assets. The reason for this is that they are associated with various characteristics of knowledge, namely, non-rivalrous, increasing returns, and non-additives, which are the resources with strategic benefits. Therefore, it is estimated that this knowledge will have a vital position in the future, urging the necessity of KM.

$\mathrm{KM}$ is an approach emphasized on the task of an organization, which is to understand how and when knowledge management must be supported, how to use the created accumulation of knowledge for increasing productivity, understand knowledge and its creation and utilization, know the value of knowledge and the knowledge-based management, and identify the relationship between knowledge and the organizational motivation level. KM has been adopted in numerous sectors and organizations, including colleges and universities. Nevertheless, most of them have not implemented this system (Agarwal \& Marouf, 2014). Therefore, a description of the current reality about the implementation of KM is required.

Cheng (2014) defines KM as a systematic and integrative process to coordinate organizational activities and programs to decide, use, share, create and store knowledge, follow-up on the information and the capabilities of individuals and groups in pursuing organizational objectives. It reveals that KM is required in organizational activities in deciding, using, sharing, creating, and storing knowledge and information for the benefit of the organization.

The importance of an organization to manage the knowledge of its members is intended: 1) to determine the strength (and position) of all human resources; 2) to reuse the existing (discovered) knowledge or prevent any repeated failure 
process; 3) to accelerate the process of creating new knowledge from the existing knowledge; 4) to maintain the stability of an organizational movement despite the outflow of human resources; 5) to help entities in providing collective information and experience to individual workers (Yeh, 2005).

A problem propounded by Bures (2011) is related to the tendency of institutions of higher learning to keep knowledge to themselves. The solution is a formulation of a center approach to knowledge management. Moreover, the framework for KM should be with six main pillars - human resources, culture, leadership technology, curriculum, and quality control mechanisms - and four knowledge processes - creating, storing, sharing, and applying knowledge. KM is a systematic process, by which knowledge needed for an organization to succeed is created, captured, shared, and leveraged (Laal, 2010).

The implementation of KM in educational institutions is associated with several determinants. Samad et al. (2014) found only two factors serve as contributors in the knowledge management model for high-performing schools in Malaysia, which were school culture and school strategy. Meanwhile, the factors of mission and vision, school strategy, school culture, intellectual modal, learning organization, leadership management, teamwork and learning community, knowledge sharing, new knowledge generation, and digital advancement, have significant relationships with the understanding of KM at different levels.

The contribution of KM will be significant with the support of information technology facilities as underlined by Bhusry et al. (2012), in which the intervention of information technology (IT)-based KM can be a prospective techno management tool for improving performance in the fields of teaching and learning, research, and administration. This model enables higher education institutions to proactively respond to the needs of stakeholders and obtain competences for improving institutional planning and development.

In the last decade, the Information and Communication Technologies (ICT) in KM have opened new avenues and played a major role in meeting the prevailing challenges related to sharing, exchanging, and disseminating knowledge and technologies in the higher education (Gulavani, 2013). Ramachandran et al. (2009) explicated the benefits of the implementation of KM in higher education as illustrated in Table 1.

Table 1: KM applied in a faculty in a HEI

\begin{tabular}{|c|c|}
\hline KM applications & Benefits \\
\hline $\begin{array}{l}\text { Repository of curriculum revision efforts that includes } \\
\text { research conducted, best practices, lesson learnt, etc. }\end{array}$ & $\begin{array}{l}\text { Improved quality of curriculum and programs and leveraging } \\
\text { best practices and monitoring outcomes Improved speed of } \\
\text { curriculum revision and updating }\end{array}$ \\
\hline $\begin{array}{l}\text { Repository of content arranged to facilitate } \\
\text { interdisciplinary curriculum design and development }\end{array}$ & $\begin{array}{l}\text { Improved faculty development efforts, especially for new } \\
\text { faculty members }\end{array}$ \\
\hline $\begin{array}{l}\text { Access to information related to teaching and learning } \\
\text { with technology, outcomes tracking, lessons learnt, } \\
\text { best practices, etc. }\end{array}$ & $\begin{array}{l}\text { Improved administrative services related to teaching and } \\
\text { learning with technology }\end{array}$ \\
\hline $\begin{array}{l}\text { Hubs of information in each disciplinary area, } \\
\text { including updated materials, recent publications, } \\
\text { applicable research, etc. }\end{array}$ & $\begin{array}{l}\text { Improved responsiveness by monitoring and including lessons } \\
\text { learnt from the experiences of colleagues, students' evaluation } \\
\text { or other role players' inputs }\end{array}$ \\
\hline $\begin{array}{l}\text { Repository of instructional and assessment techniques, } \\
\text { including best practices, outcome tracking, and } \\
\text { research }\end{array}$ & $\begin{array}{l}\text { Interdisciplinary curriculum design and development } \\
\text { facilitated by moving across boundaries }\end{array}$ \\
\hline $\begin{array}{l}\text { Repository of analyzed learner evaluations updated } \\
\text { each semester or year for lesson learnt and best } \\
\text { practices for the faculty }\end{array}$ & \\
\hline $\begin{array}{l}\text { Access for new educators to guides for developing } \\
\text { curriculum, working with senior staff members, } \\
\text { establishing effective teaching styles, advising do's } \\
\text { and don'ts supervising Master's and Doctoral students, } \\
\text { etc. }\end{array}$ & \\
\hline $\begin{array}{l}\text { Repository of relationships to identify curriculum } \\
\text { design task teams, guest speakers, case studies cites, } \\
\text { etc. }\end{array}$ & \\
\hline
\end{tabular}

Source: Ramachandran, et al. (2009)

Furthermore, KM applied in higher education institutions should effectively align its key resources, namely, (a) Employees (both academic and administrative staffs); (b) University content (e.g., lecture notes, programs, and policies); 
and (c) ICT infrastructure. Relevant technologies are highly recommended since they are perceived as resources that potentially improve KM (Kinyata, 2014). ICT becomes very important in KM implementation as confirmed by Anzehaie and Bai (2013) who found ICT as an effective factor in the KM of the Tehran education system and emphasize on the significance of KM.

Choy and Suk (2005) have identified eight knowledge management success factors, namely, (1) technology infrastructure; (2) organizational infrastructure; (3) balance of flexibility, evolution, and ease-of-accessibility to knowledge; (4) shared knowledge; (5) knowledge-friendly culture; (6) motivated workers (who develop, share and use knowledge); (7) means of knowledge transfer using various information technology infrastructure; and (8) senior management support and commitment. The first and the seventh of these factors relate to the existence of ICT. Dhamdhere (2015) reinforced that KM in educational institutions makes a good combination of intellectual output of the academic organizations, if preserved properly by using technology.

ICT that supports KM is not required and is not even optimal in every event. For instance, if there is a problem that has to be solved delicately and requires rich knowledge in a specific field, an expert or analyst might be the best choice. Likewise, although ICT in KM can be applied successfully to organizations of various sizes or levels, extensive investment in technology is generally practical only in medium to large enterprises. Moreover, organic approaches are generally more practical for small to medium organizations (Bergeron, 2003).

Strategies to investigate the implementation of KM will enhance the level of social interaction in organizations, since a few may be assisted technologically. ICTs provide information and knowledge sharing with new dimensions (Mathi, 2004) in KM implementation.

Nowadays, ICT has become a system of tools and information developed to provide sophisticated functions that publish, organize, visualize, contextualize, search, retrieve, and distribute knowledge, and support communication and collaboration of both individuals and organizations in social networks, which is also called as social software at a low cost. In addition, ICT is relatively easy to use and has been applied in many organizations as an advancement of the information infrastructure (Maier, 2005).

In higher education institutions, ICT is a vital equipment to support KM. In fact, the presence of sophisticated ICT infrastructure is a must for many organizations. Colleges and universities are lucid sites to explore the implementation of KM principles in the public sector, considering the history of the relationship between the academic society and the knowledge production. Meanwhile, KM offer several benefits, including better decision-making skills, improvement of academic services, and cost reduction (Metcalfe, 2006). Implementation of KM will be optimal with the support of various resources, including ICT.

Mohamad et al. (2013) affirmed the factors of leadership support and existing technology, in addition to the reward, affecting KM practices. KM requires both support and technology in which support can be in the form of a reward to the actors who improve the knowledge production. Concerning with technology, Ahmara and Hadiwidjojoc (2014) suggested that KM necessitates an organizational and cultural component that supports exchanges and disseminates knowledge and ICT infrastructure for accommodating the processes. The realization entails the support and commitment of senior management in the body of the higher education organizations.

In a survey carried out by Gasco et al. (2015) on knowledge creation and dissemination that was administered to four universities in Spain, a link was found between organizational culture and KM. Furthermore, KM must be supported by organizational culture. Logreira et al. (2016) asserted that KM must be supported by a determined commitment. Such commitments include plans, budgets, KM projects, and supporting systems. This supporting system is devised on the basis of the findings of the reality of KM research that can be used as an example of the innovated model.

Furthermore, Goodluck (2011) argued that the creation of effective and efficient organizational knowledge relies on aspects, yet the processes in budgeting for KM are complex. Every organization relatively has a distinctive scheme in budgeting; thus, a review of the budget schemes in Islamic universities is needed. Mazhar (2016) explicated the insignificant difference between the practices of KM in state and private higher education, except for the leadership in KM. Nevertheless, it is important to figure out the KM implementation in Islamic higher education institutions with the status of Public Service Agencies (BLU), since they have a distinctive management system from the non-BLU institutions. 


\section{METHODOLOGY}

The present study employs the phenomenological method as a qualitative research related to a topic. A phenomenological research attempts to understand the meaning of a phenomena and its influence on people in particular situations. Phenomenology explicates a phenomenon and its meaning for each individual by interviewing a number of individuals (Hasbiyansyah, 2008). The data collection technique in the phenomenological research is in-depth interview, supported by other techniques, such as observation and documentation.

The objects of the present study were the Islamic Universities in Indonesia with the status of Public Service Agency (BLU), which have implemented the remuneration system. They are Universitas Islam Negeri Sunan Kalijaga Yogyakarta, Universitas Islam Negeri Sunan Ampel Surabaya, and Universitas Islam Negeri Walisongo Semarang. These universities were selected because they are among the largest Islamic Universities in Indonesia, in addition to their BLU status.

The subjects of the present study were the executive management of Islamic universities, including the rector and vice rector; the head and secretary of the Research and Community Service Center (P3M), and the head of research and publication center of P3M; journal manager; the head of library; and the chairman of scientific consortium. Meanwhile, the research informants included lecturers and students of the department and structural leaders of higher education, in accordance with the research topic.

The data were collected through observations, in-depth interviews, document analysis, and FGDs. The FGDs were carried out three times and attended by journal managers, the management of P3M, and the management of libraries and scientific consortia. It was done to deepen the findings in the field and obtain comprehensive and accountable data.

Data analysis was carried out using an interactive model developed by Miles et al. (2014). This model has been widely used previously, including Madina et al. (2015), Ilyas (2016), Rahayu et al. (2015), and Susila (2015) in which the results of these studies have provided sufficient descriptions of reliable data.

The data analysis consisted of several stages, namely, data collection, data reduction, data display, conclusion, and verification. Verification is carried out continuously by seeking new information through different data sources and various methods to review similar information and gain the latest and the most reliable results.

Data obtained from the results of the analysis are non-statistical data. Meanwhile, the data in the form of figures are not the results of statistical analysis, but a description of real data obtained from the phase of data collection.

\section{DISCUSSION / ANALYSIS}

\section{Knowledge Management: A Reality in Islamic Universities}

Religion-based universities, under the umbrella of the Ministry of Religious Affairs, are similar to general universities under the Ministry of Research, Technology, and Higher Education in the implementation of the three pillars (Tri Dharma) of higher education, namely, education or learning activities, research, and community service. Research is the upstream in the knowledge development that is conveyed by lecturers to students. Furthermore, research can be verified through the program of community service. In order to stimulate the production of knowledge, various research schemes are formulated. Research schemes of State Islamic Universities examined in the present study are described in Table 2.

Table 2: Research Schemes

\begin{tabular}{|c|c|c|c|c|}
\hline \multirow[b]{2}{*}{ No } & \multirow[b]{2}{*}{ Description } & \multicolumn{3}{|c|}{ State Islamic Universities } \\
\hline & & $\begin{array}{c}\text { Universitas Islam } \\
\text { Negeri Sunan } \\
\text { Kalijaga Yogyakarta }\end{array}$ & $\begin{array}{l}\text { Universitas Islam } \\
\text { Negeri Sunan } \\
\text { Ampel Surabaya }\end{array}$ & $\begin{array}{c}\text { Universitas Islam } \\
\text { Negeri Walisongo } \\
\text { Semarang }\end{array}$ \\
\hline 1 & Capacity Building/Coaching Research & IDR 1,200 million & IDR 1,530 million & IDR 1,380 million \\
\hline 2 & $\begin{array}{l}\text { Applied Research and National Featured } \\
\text { Development }\end{array}$ & IDR 100 million & IDR 300 million & IDR 800 million \\
\hline 3 & Interdisciplinary Basic Research & IDR 82 million & IDR 410 million & IDR 205 million \\
\hline 4 & Applied Research and PTKI Development & IDR 4,125 million & IDR 300 million & \\
\hline 5 & $\begin{array}{l}\text { Basic Research on Development of Study } \\
\text { Programs }\end{array}$ & IDR 1,680 million & IDR 1,530 million & IDR 1,932 million \\
\hline 6 & Basic Scientific Integration Research & - & IDR 130 million & IDR 650 million \\
\hline 7 & International Fellowship Research & IDR 200 million & - & - \\
\hline 8 & Post-doctoral Research & IDR 175 million & - & - \\
\hline
\end{tabular}




\begin{tabular}{lllcc}
\hline \multirow{2}{*}{ No } & Description & \multicolumn{3}{c}{ State Islamic Universities } \\
& & $\begin{array}{c}\text { Universitas Islam } \\
\text { Negeri Sunan }\end{array}$ & $\begin{array}{c}\text { Universitas Islam } \\
\text { Negeri Sunan }\end{array}$ & $\begin{array}{c}\text { Universitas Islam } \\
\text { Negeri Walisongo }\end{array}$ \\
\hline 9 & International Leader Research & Kalijaga Yogyakarta & Ampel Surabaya & Semarang \\
\hline 10 & National Leader Research & IDR 320 million & - & - \\
\hline
\end{tabular}

Table 2 shows the similarity in the research scheme of UIN Sunan Kalijaga Yogyakarta, Universitas Islam Negeri Sunan Ampel Surabaya, and UIN Walisongo Semarang, especially in item 1-5. However, there is an obvious dissimilarity in the UIN Sunan Kalijaga Yogyakarta, in which there are nine types of research that cannot be classified into any scheme, under the heading of Basic Scientific Integration Research. These schemes have different budgets. Meanwhile, UIN Walisongo Semarang only allocates budget for schemes 1-3, 5, and 6. Knowledge production is supported through journal publication on the basis of the online system. Table 3 specifies the systems owned by the examined PTKIs.

Table 3: Repository of Islamic Universities Journal System

\begin{tabular}{lll}
\hline University & Repository & Number of journals \\
\hline UIN Sunan Kalijaga Yogyakarta & http://ejournal.uin-suka.ac.id/ & 61 \\
UIN Sunan Ampel Surabaya & http://ejournal.uinsby.ac.id/ & 41 \\
UIN Walisongo Semarang & http://ejournal.walisongo.ac.id/ & 24 \\
\hline
\end{tabular}

UIN Sunan Kalijaga Yogyakarta has 61 journals, consisting of 30 journals in Indonesian, one journal in IndonesianArabic, 11 journals in Indonesian-English, one journal in Arabic-English, one journal in English, four journals in English, and none in Arabic-Indonesian-English and Arabic only. Furthermore, it has one Scopus indexed journal (Al Jamiáh Journal) and 10 DOAJ indexed journals, 24 Moraref indexed journals, 10 SINTA indexed journals, and 22 Google Scholar indexed journals.

UIN Sunan Ampel Surabaya has 42 journals, consisting of 25 journals in English, seven journals in Indonesian-English, one journal in Arabic-Indonesian, and one journal in Arabic. It also has a journal intended for student scientific publications. In addition, it has two Scopus indexed journals (the Theosofi and Journal of Indonesia Islam), eight DOAJ indexed journals, 19 Moraref indexed journals, 9 SINTA indexed journals, and 23 Google Scholar indexed journals.

UIN Walisongo Semarang has 24 journals, consisting of one journal in Indonesian, one journal in Arabic-English, one journal in Arabic-Indonesian, one journal in Arabic, and one journal in English. In addition, it has five DOAJ indexed journals, 13 Moraref indexed journals, 11 SINTA indexed journals, 15 Google Scholar indexed journals, and no Scopus indexed journal.

In term of citation, among the three Islamic universities as research subjects, two of them have outstanding achievements related to KM. It is indicated by national and international repositories and indexation of journals. The initial description is in the national citation or SINTA, as presented in Table 4.

Table 4: National Citation

\begin{tabular}{llllll}
\hline University & Sinta Rank & Sinta Score & Verified Authors & Real Full-time Lecture & $\%$ \\
\hline UIN Sunan Kalijaga Yogyakarta & 64 & 1461 & 154 & 578 & 26,6 \\
UIN Sunan Ampel & 164 & 271 & 133 & 524 & 25 \\
UIN Walisongo Semarang & 92 & 872 & 164 & 410 & 40 \\
\hline
\end{tabular}

Table 4 shows that UIN Sunan Ampel Surabaya has the lowest national indexation. In the international arena, as indicated by the indexation through Scopus, the achievement of Islamic universities can be seen in Table 5.

Table 5: International Citation - Scopus

\begin{tabular}{llll}
\hline University & SCOPUS & Google & Research Output Scopus \\
\hline UIN Sunan Kalijaga Yogyakarta & & & \\
Document/Journal Articles & 47 & 2259 & 17 \\
Citation/Book Chapters & 209 & 14071 & 11 \\
$\begin{array}{l}\text { Conference Papers } \\
\text { UIN Sunan Ampel Surabaya }\end{array}$ & - & - & 19 \\
$\begin{array}{l}\text { Document/Journal Articles } \\
\text { Citation/Book Chapters }\end{array}$ & 38 & 1313 & 30 \\
Conference Papers & - & - & 3 \\
UIN Walisongo Semarang & - & - & 5 \\
Citation/Book Chapters & 13 & 1967 & 11
\end{tabular}




\begin{tabular}{llll}
\hline University & SCOPUS & Google & Research Output Scopus \\
\hline Citation/Book Chapters & 21 & 8983 & 1 \\
Conference Papers & - & - & 1 \\
\hline
\end{tabular}

Islamic universities (PTKIs) are the subjects of the present study and show a progress in maintaining their KM. It is reflected from the media utilized as the circulation of knowledge, namely, Internet service subscription. The budget allocated by the subjects to this service is presented in Table 6 .

Table 6: Internet Service Subscription

\begin{tabular}{lllll}
\hline \multirow{2}{*}{ No } & University & 2016 & 2017 & FISCAL YEAR \\
\hline 1 & UIN Sunan Kalijaga Yogyakarta & IDR 2.400.000.000,00 & IDR 2.400.000.000,00 & IDR 2.500.000.000,00 \\
2 & UIN Sunan Ampel Surabaya & IDR 2.000.000.000,00 & - & IDR 2.500.000.000,00 \\
3 & UIN Walisongo Semarang & IDR1.600.000.000,00 & - & IDR $1.800 .000 .000,00$ \\
\hline
\end{tabular}

Table 6 shows the increase of approximately 45\% in the Internet service subscription in 2017 to 2018, despite the insignificant increase in 2016 to 2017. The increase in UIN Sunan Kalijaga Yogyakarta was relatively stable and was different from UIN Sunan Ampel and UIN Walisongo Semarang, which do not allocate a specific budget for Internet service subscription.

The magnitude of Internet service subscription has an impact on internal access carried out by both educators and staff members. It is noticeable in the repository and library website of each university. UIN Sunan Kalijaga Yogyakarta through its repository (http://digilib.uin-suka.ac.id/) and library (https://lib.uin-suka.ac.id/) has provided access to undergraduate thesis, thesis, dissertation, journal or proceeding, and digital books. UIN Sunan Ampel Surabaya provides repository (http://digilib.uinsby.ac.id/) and library (http://library.uinsby.ac.id/? page_id=106) to access undergraduate thesis, thesis, dissertation, journal, and proceeding. Meanwhile, UIN Walisongo Semarang also provides access to numerous sources via repository (http://eprints.walisongo.ac.id/).

The subject is the most complete collection in UIN Sunan Kalijaga Yogyakarta. This university has almost all types of sources of collection, although the download access is limited for the internal circle. The number of its collections is 26877, while UIN Sunan Ampel Surabaya has 18309 and UIN Walisongo Semarang has 7823 collections.

The ICT has supported the KM implementation and its presence in higher education as a tool for knowledge circulation is compulsory. This finding has been revealed by Kinyata (2014) who emphasized the function of Internet services to support information technology, especially as a tool to store and disseminate knowledge. Nevertheless, Internet services must be supported by institutional budget policies, as mentioned previously.

The number of collections owned by a university is the result of the rector's policy concerning with the obligatory for the academic society to conduct and produce scientific works. The subjects in the present study have such policies. The UIN Sunan Kalijaga Yogyakarta issued the Rector's decree of 1.5/2016 on the requirement of scientific work for the academics of UIN Sunan Kalijaga Yogyakarta, The UIN Sunan Ampel Surabaya issued the Rector's decree of Un.07/1/KS.01.2/SK/89/P/2016 on the requirement of scientific work for the academics of UIN Sunan Ampel Surabaya, and the UIN Walisongo Semarang issued the Rector's decree of No. 304/2017 by considering the Minimum Service Standards for Academics.

The executive management of Islamic universities are serious in promoting KM of the academic society. It is also accelerated by the compensation for the KM performance, particularly in the academic field through assessment rubrics. Individual performance is transformed in the form of points of remuneration and payment. The policy related to the remuneration system has been issued by UIN Sunan Kalijaga Yogyakarta through the Rector's decree No. 26/2016, concerning the Guidelines for the Implementation of Remuneration for Public Service Agencies of UIN Sunan Kalijaga Yogyakarta in 2016, by UIN Sunan Ampel Surabaya through the Rector's decision and performance assessment, and by UIN Walisongo Semarang through the Rector's decree No. 98/2017. The guidelines for implementing the remuneration for Public Service Agencies of UIN Walisongo Semarang are considered. These policies indicate the impact of management support on the performance of scientific publications, even though such policies are only limited to the higher education institutions with the status of the Public Service Agency (BLU).

KM implementation is also reflected from the websites of each institution. The display of website must contain at least three languages, namely, Indonesian, English, and Arabic, for broadening its range. Nevertheless, UIN Sunan Ampel and UIN Walisongo Semarang have not provided the feature of foreign language for their websites. It is different from UIN 
Yogyakarta that has applied three languages (Indonesian, English, and Arabic) for the visitors and enabled them to take advantage of the knowledge developed by the university.

The display of the website is also supported by the content related to KM. The websites owned by the subjects of the present study have complete content that can be accessed by academics throughout the world. The provision of accessible information or knowledge affect the rank of these universities, as presented in Table 7.

Table 7: The Rank of Islamic University Official Website

\begin{tabular}{lcccc}
\hline \multicolumn{1}{c}{ University } & \multicolumn{3}{c}{ Rank } \\
& International & Asia & Southeast Asia & National \\
\hline UIN Sunan Kalijaga Yogyakarta & 4183 & 1583 & 141 & 45 \\
UIN Sunan Ampel Surabaya & 4715 & 1775 & 176 & 62 \\
UIN Walisongo Semarang & 4393 & 1669 & 1557 & 50 \\
\hline
\end{tabular}

\section{The Design of KM Implementation in Islamic Universities}

Currently, the system of KM implementation is designed on the production, storage, and distribution of knowledge. The present study has disclosed the implementation of KM in Islamic higher education institutions. It is distinctive from the results found by Agarwal and Marouf (2014) in which most of the sectors of higher education have not applied KM in their system.

In terms of production of knowledge, the existing research (of various schemes and budgets) acts as the basis. Furthermore, lecturers still dominate the knowledge production, students have a small potion, and functional positions have none except for an insignificant number of librarians. In terms of the knowledge storage, the system can be divided into printout and electronic categories. The printout category is represented by the printout journal and the proceeding is owned by the study program. The electronic category is depicted from online journal system (OJS), repository, and website. This category not only serves as a means of knowledge storage, but also as a knowledge distribution tool. Knowledge distribution is carried out through scientific publications through the OJS, repositories, and websites, as well as scientific consortiums and conventional lectures.

Knowledge distribution is carried out through scientific publications via the OJS, repositories, and websites, and through consortiums and conventional classes. It shows that knowledge is not stored for self-interest, but instead can be consumed by others. Nevertheless, this result is different from Bureš (2011) in which institutions have a tendency to store knowledge for themselves.

Furthermore, the knowledge storage and distribution tools will be suboptimal without the provision of Internet service subscription and budget. Knowledge management system must be outlined in the form of policies at the institutional level. The policy is later realized in the form of a Rector's decree. The flowchart to describe the implementation of KM in the State Islamic Universities (PTKIN) is a result of the analysis of the present study, which is presented in Figure 1.

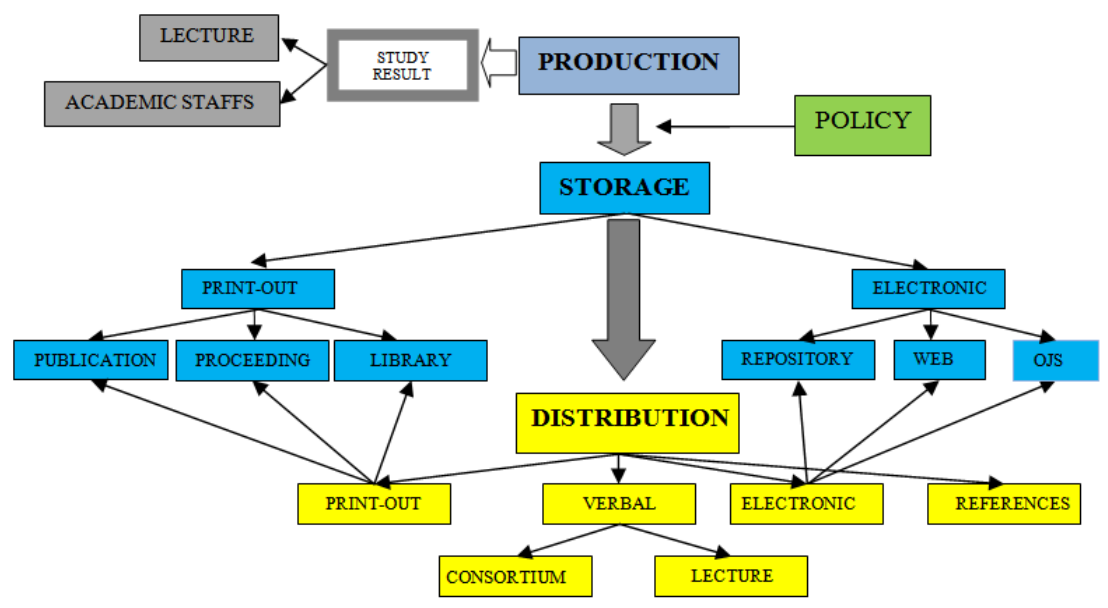

Figure 1. Knowledge Management Flowchart in PTKIN

$\mathrm{KM}$ in State Islamic Universities in Indonesia is embodied in various policies provided by the executive management of the institution, which is then followed-up by stakeholders of the sub-institutions. The commitment in the body of an organization in KM reaffirms the findings reported by Logreira et al. (2016) and Gasco et al. (2015), in which KM is 
upheld by the power of commitment. In this context, the commitment is about the policies issued by the top management and executed by the sub-ordinates as supported by the organizational culture. The present study corroborates the significance of commitment and organization culture mentioned by previous studies, including Ahmara and Hadiwidjojoc (2014), Gasco et al. (2015), and Logreira et al. (2016).

The provision of a varied budget has an impact on the KM development as reflected in journal management, repository management, website management, and management of scientific consortium of each university. Budgeting supports the effectiveness of KM as suggested by Goodluck (2011).

Each State Islamic University has its own strategies and approaches in maintaining its KM. The implementation of KM is aligned with the three pillars of higher education (Tridharma Perguruan Tinggi). The motivation given to academic staff for conducting research and publishing for public's knowledge should be a continuing process.

Rakhmah (2017) unveiled the significance of each institution to have a KM strategy. It can be a model, for instance a knowledge-based organization model, or relevant policies. In this case, policy becomes a strategy used by the Islamic university in the implementation of $\mathrm{KM}$, which must be designed on the basis of the policy structure captured and understood by all institutional instruments. The flowchart of integrated KM processes results in an increase in the number of works. The process of organized publication of knowledge enables all parties to disseminate knowledge.

The autonomy in accessing and publishing knowledge must be the consciousness of scientific actors. Nevertheless, it can be supported through policies and frameworks for Islamic universities with their various characteristics. In the UIN Sunan Kalijaga, the policy is to possess and save scientific work for the academic society. In the UIN Sunan Ampel, the policy of publishing scientific works is set forth in the MoU between research institutes and researchers. Meanwhile, in the UIN Walisongo, the policy is manifested in the obligation to collect scientific papers.

The present study has shown that KM implementation is highly linked to policies, budgets, human resource, processes, and technology. It is different from the findings of Ramin et al. (2013) in which there are three main determinants, namely, organization, human resources, and technology, for the implementation of KM in companies. Nevertheless, the present study confirms the findings of Savitri et al. (2013) in which the interactions between human resources, processes, and technology are the key factors in organizational KM, and a systematic approach is insufficient for carrying out KM processes and the absence of learning and cultural sharing are the main reasons behind the sub-optimal KM implementation in higher education institutions. The present study differs from the previous studies in terms of policy, budget, and process.

The present study identified the role of policy makers in KM implementation. The findings of Yaakub et al. (2014) are ascertained in which the practice of KM in higher education institutions is not formative and is able to stand alone without support from top management. There is a need to create formative standards of KM implementation in higher education institutions to enable the rearrangement of systematic practices in their infrastructure and strategic activities. $\mathrm{KM}$ can be effective with the support of management system from the process of production, storage and distribution with ICT, funding, research schemes, research budgets, journals, journal budgets, OJS, repositories, websites and Internet service budget, and policy support.

\section{CONCLUSION}

The knowledge flow of Islamic universities (PTKI) is represented by the implementation of the three pillars of higher education, namely, learning, research, and community service. Knowledge production must be supported by the distribution of knowledge through journals, especially OJS. Institutional policy is the main initiation in KM. The indicator of KM flow is examined from the development of the journal reputation of each university.

The system of KM implementation is designed on the basis of production, storage, and distribution of knowledge. In terms of knowledge production, the existence of research (various schemes and budgets) has been the indicator. Ideally, the number of knowledge production aspects must be comparable to the number of human resources in a university. The human resources include educators (lecturers), academic staff (particularly non-lecturer functional positions and general functional positions), and students.

In terms of knowledge storage, there are two schemes of offline (printout) and online (electronic) categories. The first category is represented by printout journals or books and the number of human resources. The electronic category is represented by OJS, repository, and website. This category not only functions as a means of knowledge storage, but also as a knowledge distribution tool. 
Nevertheless, the storage and distribution tools will not be effective without the support of Internet service policies and budgets. Essentially, KM requires specific policies due to its non-autonomy. Production of new knowledge is limited to lecturers' works, while the works generated by other functional staffs, students, community service, and scientific consortium are not optimally managed.

\section{LIMITATION OF THE STUDY}

The present study explains KM sourced from the findings of knowledge production generated by lecturers and other academic staff members. Meanwhile, those generated by students, community service, and scientific consortium have not been noticeable. Further research is suggested in the design of KM implementation in the students' knowledge production, community service, and scientific consortium.

\section{REFERENCES}

Agarwal, N.K. \& Marouf, L.N. (2014). Initiating knowledge management in Colleges and Universities: A template, International Journal of Knowledge Content Development \& Technology, 4 (2) 67-95. DOI: 10.5865/IJKCT.2014.4.2.067.

Ahmara, A. G. O., \& Hadiwidjojoc, A. R.D. (2014). The impact of knowledge management, learning organization, and educations organization on organization performance: a case in Brawijaya University, Asia-Pacific Management and Business Application, 3 (1) 28 - 47. DOI: http://dx.org/10.21776/ub.apmba.2014.003.01.3.

Anzehaie, Z.H., \& Bai, N. (2013). The role of information technology in successful knowledge management (Case study: Tehran's physical education college). Pelagia Research Library Advances in Applied Science Research, 4(6), 197200 .

Bergeron, B. (2003). Essentials of knowledge management. New Jersey: John Wiley \& Sons, Inc.

Bhusry, M., Ranjan, J., \& Nagar, R. (2012). Implementing knowledge management in higher educational institutions in India: A conceptual framework. Liceo Journal of Higher Education Research 7(1). doi: http://dx.doi.org/10.7828/ljher.v7i1.21.

Bures, V., Griffin, D., Hackett, D., Kročitý, P., \& Kubička, E., (2011). Rethinking of knowledge management introduction at teaching universities: the framework development, Problems of education in the 21 st century, 32(32), 33-46.

Burstein, F., McCullough, S. Z. G., Oliver, G., Symonds, J., \& Brown, M. (2003). Leading knowledge management strategies in Australia and New Zealand: a comparative study of public and private sector organizations. Paper on 14th Australasian Conference on Information Systems Page 1, 26-28, Perth, Western Australia.

Cheng, E. C. K. (2014). Knowledge management for school education. Hongkong: Springer. 8 page 83. doi. 10.1007/978-981-287-233-3.

Choy, C.S., \& Suk, C. Y. (2005). Critical factors in the successful implementation of knowledge management. Journal of Knowledge Management Practice, June 2005. Retrieved from http://www.tlainc.com/articl90.htm. (Accessed on January 08, 2018).

Dhamdhere, S.N. (2015). Importance of knowledge management in the higher educational institutes. Turkish Online Journal of Distance Education-TOJDE, 16(1) Article 11. Retrieved from https://files.eric.ed.gov/fulltext/EJ1092819.pdf. (Accessed on October, 2017).

Djajadiningrat, S.T. (2005). Mengelola pengetahuan dan modal intelektual dengan pembelajaran organisasi: Suatu gagasan untuk Institut Teknologi Bandung [Knowledge management and intellectual capital through organizational learning: A notion for Institut Teknologi Bandung]. Paper presented at "Sidang Terbuka ITB Peringatan Dies Natalis Institut Teknologi Bandung ke-46”, 2 March 2005, Kampus Institut Teknologi Bandung.

Drucker Institute. (2011). A Wealth of Knowledge. Retrieved from http://www.druckerinstitute.com/2011/03/a-wealth-ofknowledge/. (Accessed on December 08, 2018).

Gasco,V. J. P., Pardo, I . Q., Moreno, F. C, \& Veinhardt, J. V. (2015). Knowledge management in R\&D teams at a spanish technical university: measurement and relations with organizational culture, Inzinerine EkonomikaEngineering Economics, 26(4), 398-408. http://dx.doi.org/10.5755/j01.ee.26.4.9885.

Goodluck, I. (2011). Budgeting for knowledge management in organizations. Chinese Librarianship: an International Electronic Journal, 32. Retrieved from http://www.iclc.us/cliej/cl32goodluck.pdf . (Accessed on December 03, 2018). 
Gulavani, U. T., \& Joshi, M.J. (2013). A Review of Literature on Knowledge Management using ICT in Higher Education. IJCTA. Retrieved from www.ijcta.com. (Accessed on January 12, 2018).

Hasbiyansah. O. (2008). Pendekatan fenomenologi: Pengantar praktik penelitian pada ilmu sosial dan komunikasi [Phenomonological approach: Introduction to research practices in social science and communication]. JurnalMediator, 9(1), 163-180.

Ilyas. (2016). Pendidikan karakter melalui home schooling [Character education through home schooling]. Journal of Nonformal Education, 2(1), 92-98.

Kinyata, G.L. (2014). The role of knowledge management in higher education institutions: A case study from Tanzania. International Journal of Management, Knowledge and Learning, 3(1), 43-58.

Laal, M. (2010). Knowledge management in higher education, Procedia Computer Science 3 (2011) 544-549. doi:10.1016/j.procs.2010.12.090.

Logreira, H. P., Musa, R.Z., \& Zapata, J.V. (2016). Relation analysis of knowledge Management, research, and innovation in university research groups, Journal of Technology Management \& Innovation (C) Universidad Alberto Hurtado, Facultad de Economía y Negocios, 11(4), 5-11.

Madina, R. I., Wilopo \& Said, A. (2015). Faktor yang mempengaruhi implementasi regulasi daerah terkait penerimaan pajak reklame [Factors in the implementation of regional regulation on advertisement tax], Jurnal Perpajakan (JEJAK), 6(2). 1-10.

Maier, R., Hädrich, T., \& Peinl, R. (2005). Enterprise knowledge infrastructures. Springer-Verlag Berlin, eBook X, 386, doi.10.1007/3-540-27514-2.

Mathi, K. (2004). Key success factors for knowledge management. Master Thesis MBA: International Business Management\& Consulting. Internationales Hochschul institut Lindau, University of Applied Sciences/ FH Kempten, Germany. Retrieved from http://hosteddocs.ittoolbox.com/km21105.pdf. (Accessed on April 26, 2018).

Mazhar, M.S. (2016). Knowledge management practices: a Comparative study of public and private sector universities at lahore, Journal of Quality and Technology Management, 12 (1), 81 - 90.

Metcalfe, A. S. (2006). Knowledge management and higher education: a critical analysis. The University of British Columbia.

Miles, M. B., Huberman, A. M., \& Saldana, J. (2014). Qualitative data analysis,3rd Edition. London: Sage Publication Ltd.

Mishra, R. (2013). Globalisation and higher education threat or opportunity, International Journal of Humanities \& Social Sciences, 1 (01), 39-47.

Mohamad, R., Manning, K., \& Tatnall, A. (2013). Knowledge management in university administration in Malaysia. In: Passey D., Breiter A., Visscher A. (eds) Next Generation of Information Technology in Educational Management. ITEM 2012. IFIP Advances in Information and Communication Technology, vol 400,76-85. https://doi.org/10.1007/978-3-642-38411-0_7

Rahayu, R., Haryono, B. S., \& Mindarti, L. I. (2015). Efektivitas partisipasi masyarakat dalam penyusunan program legislasi daerah di lingkungan pemerintah Kota Batu [Effectiveness of community participation in the preparation of regional government program of Batu city]. REFORMAS Jurnal Unitri, 5(1), 31-45.

Rakhmah, S. N. (2017). Strategi knowledge management untuk meningkatkan pengetahuan berdasarkan knowledgebased organizational model (Studi kasus PT Telekomunikasi Indonesia Jakarta) [Strategy of knowledge-based organizational model to improve knowledge (Case study in PT Telekomunikasi Indonesia Jakarta). Information System for Educators and Professionals, 1(2), 115-124.

Ramachandran, S. D., Chong, S.C., \& Ismail, H. (2009). The practice of knowledge management processes: A comparative study of public and private higher education institutions in Malaysia. VINE: The journal of information and knowledge management systems, 39(3), 203-222.

Ramin, N. A. M., Taib, K. M., Hashim, D. M., Noordin, S. A., \& Yasin, S. M. (2013). Knowledge management implementation in a government research institute in Selangor, Malaysia. Communications of the IBIMA, Article ID 476066, Retrieved from http://ibimapublishing.com/articles/CIBIMA/2013/476066/. (Accessed on June 15, 2017).

Rowley. J. (2000). Is higher education ready for knowledge management?, International Journal of Educational Management, 14(7), 325-333. https://doi.org/10.1108/09513540010378978. 
Samad, R. S. A., Sukor, M. I. R., Syah, D., \& Muslihah, E. (2014). Understanding the implementation of knowledge management in high-performance schools in Malaysia. SAGE Open October-December, 1-7. https://doi.org/10.1177\%2F2158244014561206.

Savitri, F., Sahiraliani, D., \& Yakhusna, R. (2013). Knowledge management implementation within the higher education institutions In Bandung, Indonesia's city ofeducation. South East Asia Journal of Contemporary Business, Economics and Law,2(1), Retrieved from http://seajbel.com/wp-content/uploads/2014/07/Knowledge-ManagementImplementation-Within-The-Higher-Education-Institutions-In-Bandung-Indonesia\%E2\%80\%99s-City-OfEducation-Firly-Savitri-Dienni-Sahiraliani-Rizqi-Yakhusna.pdf . (Accessed on July 15, 2018).

Shafique, F. (2015). Knowledge management In higher education: Applicability of Lkmc model in Saudi universities. Computer Science \& Information Technology (CS \& IT) CCSEA, DKMP, AIFU, SEA(pp. 175-181). http://airccj.org/CSCP/vol5/csit53315.pdf. (Accessed on July 27, 2018).

Sharma, M., \& Kaur, M. (2016). Knowledge management in higher education institutions. IRA-International Journal of Management \& Social Sciences, 4(3), 548-555. doi:http://dx.doi.org/10.21013/jmss.v4.n3.p4.

Susila, I. (2015). Pendekatan kualitatif untuk riset pemasaran dan pengukuran kinerja bisnis [Qualitative approach for marketing and assessment of business performance]. BENEFIT Jurnal Manajemen dan Bisnis, 19(1), 12-23.

Yaakub, M. B., Othman, K., \& Yousifis, A. F. (2014). Knowledge management practices in Malaysian higher learning institutions: A review on selected cases. International Journal of Education and Research, 2(1). Retrieved from http://www.ijern.com/journal/January-2014/37.pdf . (Accessed on December 13, 2017).

Yeh, Y. M. C. (2005). The implementation of knowledge management system in Taiwan's higher education. Journal of College Teaching \& Learning (TLC), 2(9). https://doi.org/10.19030/tlc.v2i9.1861.

Yusoff, M.Y.M., Mahmood, A.K., \& Jaafar, J. (2012). A study of KM process and KM enabler in a Malaysian community college. Journal of KM Practice, 13(1). Retrieved from www.tlainc.com/articl297.htm. (Accessed on February 19, 2018). 